\title{
The Effect of Severe Early Malnutrition on Cellular Growth of Human Brain
}

\author{
Myron Winiak ${ }^{[19]}$ and Pedro Rosso \\ Department of Pediatrics, Cornell University Medical College, New York, N.Y., USA; \\ and University of Chile, Santiago, Chile
}

\begin{abstract}
Extract
In ten 'normal' brains, obtained from well-nourished Chilean children who died accidentally, weight, protein, and DNA and RNA content were all normal when compared with those values derived from similar children in the United States. Table I demonstrates the values obtained in these children. In nine infants who died of severe malnutrition during the first year of life, there was a proportional reduction in weight, protein, and RNA and DNA conțent. The actual values for these determinations are given in table II. The number of cells was reduced but the weight or protein per cell was unchanged Three infants who weighed less than 2,000 grams_at birth (Infants 2, 3, and 4, table II) were the most severely affected. These data are similar to previous data in animals and demonstrate that in children, severe early malnutrition can result in curtailment of the normal increase in brain cellularity with increase in age.
\end{abstract}

\section{Speculation}

At present there is growing concern that malnutrition early in life may retard normal development. Studies conducted in Africa, in South America, in Mexico, in Guatemala, and in our own country suggest that this is true. Retarded brain growth has also been suspected in malnourished children. The decreased head circumference often noted has been cited as evidence for retardation in brain growth. Although numerous chemical changes secondary to undernutrition have been shown in brain of animals, similar studies have not been available in human brain. This study demonstrates such changes and establishes that cell division is curtailed in human brain by severe early malnutrition. The data provide yet another link in the ever lengthening chain of evidence linking malnutrition to faulty brain growth and development.

\section{Introduction}

Total content of DNA reflects cell number in any organ made up primarily of diploid cells [2]. Although some tetraploidy has been reported in brain [6], the overwhelming majority of both neurones and glia are diploid. Total brain DNA reflects the total number of brain cells, and the ratio of protein to DNA or that of
RNA to DNA reflects the average amount of protein or RNA per cell.

In rats, malnutrition at a time when brain cells are actively dividing curtails cell division and results in an ultimate reduction in total brain cell number [13]. This reduction in cell number will occur if the rats are malnourished from birth or if their mothers are malnourished during pregnancy [17], and will persist even 
if the animals are later given an adequate diet. In contrast, 'overfeeding' rats from birth to weaning will increase the rate of cell division in brain [15]. This increase in the rate of cell division will occur even after a short period of malnutrition if rehabilitation is begun while cell division is still actively occurring [16]. It would appear that the state of nutrition from before birth to 17 days of age will influence the rate of cell division and the ultimate number of cells in rat brain.

Examination of a series of 'normal' human brains collected in the United States from therapeutic abortions and from children who died from accidents or poisonings has demonstrated that DNA content increases linearly until birth, more slowly until 6 months of age, and very little thereafter [11]. It seems probable, therefore, that if the response to malnutrition in human brain is analogous to the response in rat brain, the critical postnatal period during which cell division could be curtailed would be the first six months of life.

\section{Materials and Methods}

The studies described here were carried out in two groups of children in Santiago, Chile. In the first group, all ten children were well nourished and were within the normal height and weight curves for both Chilean [1] and American children [10]. They showed no clinical evidence of malnutrition and died acutely of accidents or poisonings. Two fetuses studied were the products of therapeutic abortions for psychiatric reasons.

In the second group, all the infants died during the first year of life and showed typical signs of severe third degree malnutrition. They were all well below the third percentile for height and weight and presented a clinical picture of severe infantile marasmus. In none of these nine cases was breast feeding practiced; the major source of food was a liquid made of flour and water.

Brains were removed within one hour of death and immediately frozen. These were homogenized in toto to a $20 \%$ suspension in distilled water. DNA, RNA, and protein were separated by a modification of the Schmidt-Thannhauser procedure [8]. Incorporation and recovery studies previously performed using rat brain showed that the methods used were effective for fractionation of these components of the central nervous system. DNA was determined by Burton's modification of the diphenylamine reaction [4]. When verified by direct ultraviolet spectrophotometry, there was agreement within $5 \%$ between the methods. RNA was determined by the orcinol reaction [5] and protein by the method of Lowry et al. [7]. Complete details of these methods have been published elsewhere [11, $12,14]$.

\section{Results}

In all cases, the normally nourished infant in Santiago showed weights and amounts of protein, RNA, and DNA content in brain comparable to that of the population previously studied in the United States (figs. 1-4). The brains of the nine infants who died of severe malnutrition all showed reduced weights and reduced quantities of protein, RNA, and DNA content (figs. 1-4). In three infants (Infants 2, 3, and 4, table II), DNA content was approximately $40 \%$ of that expected. These three infants all weighed less than 2,000 grams at birth, indicating that they were prematures or had suffered fetal growth retardation. Unfortunate-

Table I. Control population

\begin{tabular}{|c|c|c|c|c|}
\hline \multirow[t]{2}{*}{ Age } & Weight & $\begin{array}{l}\text { Pro- } \\
\text { tein }\end{array}$ & RNA & DNA \\
\hline & \multicolumn{2}{|l|}{$\mathrm{g}$} & \multicolumn{2}{|c|}{$\mathrm{mg}$} \\
\hline 15 weeks gestation & 32 & 1.8 & 28.3 & 22 \\
\hline 18 weeks gestation & 54 & 2.4 & 47.6 & 48 \\
\hline 36 weeks gestation & 280 & 10.8 & 315 & 520 \\
\hline 39 weeks gestation & 214 & 14.2 & 402 & 580 \\
\hline $13 / 4$ months & 312 & 19.8 & 501 & 706 \\
\hline 2 months & 408 & 22.3 & 620 & 790 \\
\hline $53 / 4$ months & 570 & 29.0 & 732 & 880 \\
\hline $61 / 2$ months & 602 & 31.8 & 924 & 910 \\
\hline $81 / 2$ months & 720 & 40.0 & 1040 & 920 \\
\hline $11 \mathrm{t} / 2$ months & 850 & 49.1 & 1306 & 910 \\
\hline
\end{tabular}

Each set of values represents value for total brain of a single patient. Determinations were carried out in triplicate with less than $2 \%$ variation in all three samples.

Table II. Malnourished population

\begin{tabular}{|c|c|c|c|c|}
\hline \multirow[t]{2}{*}{ Age } & Weight & $\begin{array}{l}\text { Pro- } \\
\text { tein }\end{array}$ & RNA & DNA \\
\hline & \multicolumn{2}{|l|}{$\mathrm{g}$} & \multicolumn{2}{|c|}{$\mathrm{mg}$} \\
\hline $1 / 2$ month & 208 & 10.2 & 345 & 512 \\
\hline $13 / 4$ months & 136. & 7.4 & 210 & 380 \\
\hline $31 / 2$ months & 105 & 7.6 & 200 & 300 \\
\hline $51 / 2$ months & 132 & 7.4 & 160 & 315 \\
\hline 6 months & 400 & 15.8 & 560 & 700 \\
\hline $63 / 4$ months & 420 & 18.2 & 595 & 720 \\
\hline 7 months & 386 & 15.6 & 510 & 680 \\
\hline 9 months & 505 & 20.3 & 660 & 690 \\
\hline 11 months & 557 & 19.0 & 605 & 510 \\
\hline
\end{tabular}

Each set of values represents value for total brain of a single patient. Determinations were carried out in triplicate with less than $2 \%$ variation in all three samples. 
ly, gestational age records were not available to make this distinction. The reduction in weight (fig. 1), protein (fig. 2), and RNA (fig. 3) is roughly proportional to the reduction in DNA (fig. 4) and, thus, the ratios are normal, suggesting that the average protein or RNA content per cell is normal. If the data are plotted against weight instead of age, there is no reduction in DNA content in brain, and the reduction in cell number is proportional to the reduction in the weight of these children.

\section{Discussion}

'These data demonstrate that the brains of well-nourished Chilean children who died accidentally contain

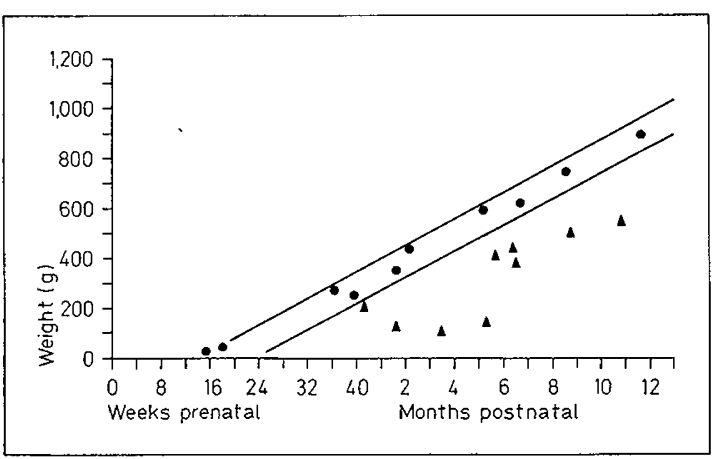

Fig. 1. Lines indicate normal range for US population [11].

- indicates normal Chilean children.

$\boldsymbol{\Delta}$ indicates Ghilean children who died of severe malnutrition during the first year of life.

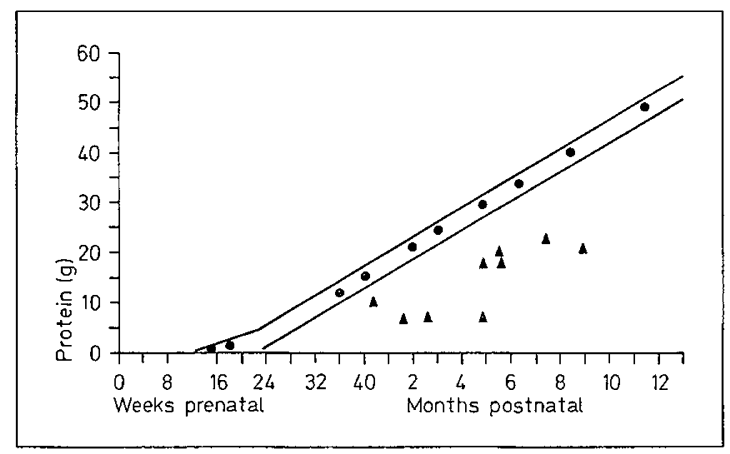

Fig.2. Lines indicate normal range for US population [11].

- indicates normal Chilean children.

$\Delta$ indicates Ghilean children who died of severe malnutrition during the first year of life. the same number of cells as the brains of chilaren accidentally dying in the United States. In contrast, children who died of severe malnutrition (marasmus) during the first year of life showed a reduced DNA content in brain. The data also suggest that the younger the child when malnutrition strikes, the more marked the effects. The three children in this study who weighed less than 2,000 grams at birth had a $60 \%$ reduction in DNA content in brain. These results imply either that the brain of a very small infant may be more sensitive to severe postnatal malnutrition or that intrauterine malnutrition had already occurred in these three infants. Better prenatal case histories will have to be collected to separate these possibilities.

The retardation in brain growth in all nine children

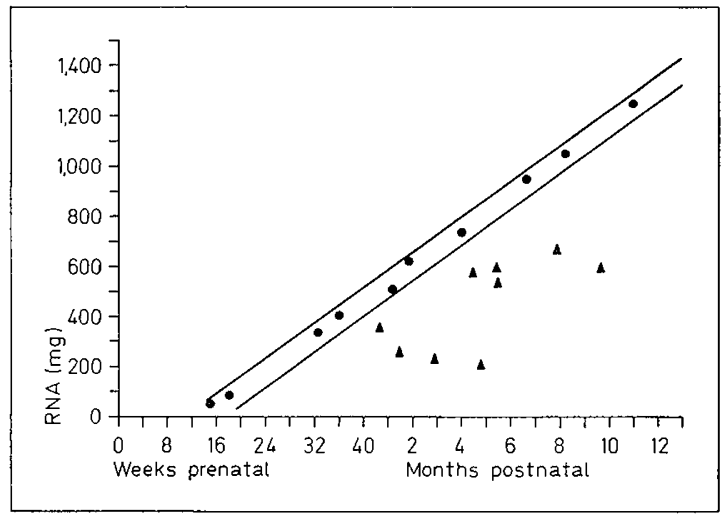

Fig. 3. Lines indicate normal range for US population [11].

- indicates normal Chilean children.

$\Delta$ indicates Chilean children who died of severe malnutrition during the first year of life.

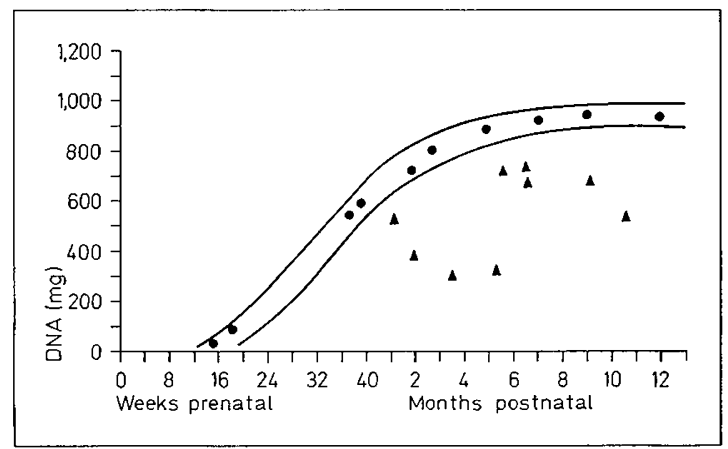

Fig.4. Lines indicate normal range for US population [11].

- indicates normal Chilean children.

$\Delta$ indicates Chilean children who died of severe malnutrition during the first year of life. 
studied can be entirely explained by the decreased number of brain cells. The protein/DNA ratio (protein per cell) remained unchanged. The retardation in brain growth, which has been inferred from measurements of head circumference [9] and demonstrated more directly by reduced brain weight [3], was a result of the curtailment of cell division. The brains of these children contained fewer cells than brains of wellnourished children of similar age.

\section{Summary}

Total brain weight and protein, RNA and DNA content were studied in children who died of severe malnutrition during the first year of life in Santiago, Chile. Brains of the well-nourished children were the same weight and contained the same quantities of DNA, RNA and protein as brains from a comparable population studied in the United States. In contrast, the brains of the infants who died of malnutrition were proportionally reduced in weight and in nucleic acid and protein content. These data indicate that severe early malnutrition retards cell division in human brain.

\section{References and Notes}

1. Barja, I.; Fuente, M.; Ballester, D.; MonckeBERG, F. y Donoso, G.: Peso y talle de pre-escolores Chilenos urbanos de tres niveles de vida. Rev. chil. Pediat. 36: 525 (1965).

2. Boilvin, A.; Vendrely, R. et Vendrely, C.: L'acide desoxyribonucléique du noyau cellulaire, dépositaire des caractères héréditaires; arguments d'ordre analytique. C.R. Acad. Sci. 226: 1061 (1948).

3. BRown, R.E.: Decreased brain weight in malnutrition and its implications. E. Afr.med.J. 42: 584 (1965).

4. Burton, K.: A study of the conditions and mechanisms of the diphenylamine reaction for the colorimetric estimation of desoxyribonucleic acid. Biochem. J. 62: 315 (1956).

5. Dische, A.: In The nucleic acids (ed. Chargaff, E. and Davidson, J.N.), vol.I (Academic Press, New York 1955).
6. Lapham, L.W.: Tetraploid DNA content of Purkinje neurons of human cerebellar cortex. Science 159: 310 (1968).

7. Lowry, O.H.; Rosebrough, N.J.; FAar, H. L. and Randall, R.J.: Protein measurement with the folin phenoll reagent. J. biol. Chem. 193: 265 (1951).

8. Schmidt, G. and Thannhauser, S.J.: A method for the determination of desoxyribonucleic acid, ribonucleic acid and phosphoproteins in animal tissues. J. biol. Ghem. 161: 83 (1945).

9. Stock, M.B. and Smythe, P.M.: Does undernutrition during infancy inhibit brain growth and subsequent intellectual development? Arch. Dis. Childh. 38: 546 (1963).

10. Stuart, H. G. and Meredith, H.V.: Use of body measurements in the school health program. Amer. J. publ. Hlth 36: 1365 (1946).

11. WINICK, M.: Changes in nucleic acid and protein content of the human brain during growth. Pediat. Res. 2: 352 (1968).

12. Wrnick, M. and Noble, A.: Quantitative changes in DNA, RNA and protein during prenatal and postnatal growth in the rat. Devclop. Biol. 12: 451 (1965).

13. Winick, M. and Noble, A.: Cellular response in rat during malnutrition at various ages. J. Nutr. 89: 3 (1966).

14. Winick, M.and Noble, A. : Quantitative changes in ribonucleic acid and protein during normal growth of rat placenta. Nature, Lond. 212: 34 (1966).

15. WinicK, M. and Noble, A.: Cellular response with increased feeding in neonatal rats. J. Nutr. 91: 2 (1967).

16. Winick, M.; Rosso, P. and Fish, I.: Cellular recovery in rat tissues after a brief period of neonatal malnutrition. J. Nutr. 95: 623 (1968).

17. Zamenhof, S.; van Marthens, E. and Margolis, F.L.: DNA (cell number) and protein in neonatal brain: Alteration by maternal dietary protein restriction. Science 160: 322 (1968).

18. This research was supported by the National Foundation Grant 1270, the Nutrition Foundation Grant 357, and the New York City Health Research Council Contract U 1769.

19. Requests for reprints should be addressed to: Myron Winick, M.D., The New York Hospital, 525 East 68th Street, New York, N.Y. 10021 (USA). 